\title{
KANDUNGAN KLOROFIL-A DAN FITOPLANKTON DI LOKASI YANG BERBEDA DI SUNGAI WULAN, KABUPATEN DEMAK
}

\author{
The Contents of Chlorophyl-a and Phytoplankton in Different Location in Wulan River, Demak Regency
}

\author{
Hilda Kumala Dewi, Boedi Hendrarto*) dan Churun Ain
}

Program Studi Manajemen Sumberdaya Perairan, Departemen Sumberdaya Akuatik

Fakultas Perikanan dan Ilmu Kelautan, Universitas Diponegoro

J1. Prof. Soedarto, SH, Tembalang, Semarang, Jawa Tengah - 50275, Telp/Fax. +6224 7474698

Email : hildakd94@gmail.com

\begin{abstract}
ABSTRAK
Sungai Wulan adalah sungai yang melewati tiga kabupaten yaitu Grobogan, Kudus dan Demak. Sungai Wulan yang terletak di Kabupaten Demak, mempunyai dua percabangan yaitu Wulan Lama dan Wulan Baru. Sungai ini digunakan oleh masyarakat untuk berbagai keperluan seperti kegiatan perikanan, domestik dan transportasi. Di hilir sungai juga terdapat daerah mangrove. Dampak dari kegiatan manusia tersebut kemungkinan akan berpengaruh terhadap kualitas perairan, hal tersebut diduga berdampak terhadap keberadaan fitoplankton serta kandungan klorofil-a. Penelitian dilakukan pada bulan Maret - April 2016 bertujuan untuk mengetahui kandungan klorofil-a, fitoplankton dan status perairan berdasarkan kandungan klorofil-a dan kelimpahan fitoplankton. Metode yang digunakan adalah metode survei lapangan dengan teknik purposive sampling. Pengambilan sampel dilakukan di tiga lokasi yang berbeda yaitu dekat pemukiman (Stasun 1), Wulan Baru (Stasiun 2), dan Wulan Lama (Stasiun 3). Analisis Kruskal-Wallis untuk mengetahui perbedaan kandungan klorofil-a antar stasiun dan analisis Cluster untuk mengetahui kemiripan berdasarkan komunitas fitoplankton dan variabel lingkungan antar stasiun. Hasil penelitian menunjukkan kandungan klorofil-a berkisar antara 0,4955 - 1,3527 mg/l. Tidak ada perbedaan yang nyata kandungan klorofil-a per stasiun pada taraf kepercayaan 95\% (0,05). Kelimpahan fitoplankton berkisar antara $9.458-12.422$ ind/l. Fitoplankton yang didapatkan terdiri dari 35 genera yang terdiri dari 5 kelas yaitu Bacillariophyceae, Cyanophyceae, Dynophyceae, Chlorophyceae dan Euglenophyceae. Stasiun 2 dan Stasiun 3 mempunyai kemiripan komunitas fitoplankton dan variabel lingkungan dibandingkan dengan Stasiun 1. Status perairan Sungai Wulan berdasarkan kandungan klorofil-a tergolong oligotrofik dan berdasarkan kelimpahan fitoplankton tergolong mesotrofik.
\end{abstract}

Kata Kunci: Klorofil-a; Fitoplankton; Sungai Wulan

\begin{abstract}
Wulan River is a river that passes through three regencies there are Grobogan, Kudus and Demak. Wulan River located in Demak Regency, has two branches there are Wulan Lama and Wulan Baru. This river has been used a lot by the residents for many activities such as fishery activities, domestic and transportation. There is also mangrove area in the downstream of Wulan River. The impact of those human activities presumably will affect the quality of the waters, it is also presumed to impact the existence of phytoplankton and the contents of chorophyl-a. This research was conducted on March - April 2016 aimed to know the contents of chlorophyl-a, the type and abundance of phytoplankton and the status of waters based on the content of chlorophyll-a and the abundance of phytoplankton. This research used survey method and purposive a sampling teqnique. The sampling was conducted in three different locations, that is in the nearby people residence (Station 1), Wulan Baru (Station 2) and Wulan Lama (Station 3). The Kruskal-Wallis analysis was used to determine differences of chlorophyll-a between the stations and Cluster analysis was used to determine similarity groups based on the phytoplankton community and environment variables between stations. The results showed chlorophyll-a range between 0,4955 - 1,3527 $\mathrm{mg} / \mathrm{l}$. There is no significant difference between the content of chlorophyll-a per station at the level of $95 \%(P<0,05)$. The abundance of phytoplankton ranged between 9.458 - 12.422 ind/l. The phytoplankton was obtained consisting of 35 genus consisted of 5 classes, namely Bacillariophyceae, Cyanophyceae, Dynophyceae, Chlorophyceae and Euglenophyceae. Both Station 2 and Station 3 had a more similarity in the community of phytoplankton and the environment variable compared to the Station 1. The status waters of the Wulan Rivers based on the contents chlorophyll-a was classified into oligotrophic and based on the abundance of phytoplankton was classified into mesotrophic.
\end{abstract}

Keywords: Chlorophyl-a; Phytoplankton; Wulan River

*) Penulis penanggungjawab

${ }^{\circ}$ Copyright by Management of Aquatic Resources (MAQUARES) 


\section{PENDAHULUAN}

Sungai adalah salah satu bagian dari ekosistem yang sangat penting bagi manusia. Umumnya air sungai di Indonesia dimanfaatkan untuk berbagai kepentingan seperti sarana pemenuhan kebutuhan sehari-hari untuk mencuci, memasak dan cuci kakus seperti di Sungai Alalak, Kalimantan Selatan (Sari et al., 2016). Manfaat sungai selanjutnya adalah sumber pengairan untuk daerah pertanian, perikanan, industri, transportasi dan sumber air minum contohnya seperti di Sungai Bengawan Solo (Wibowo et al., 2014).

Sungai Wulan adalah sungai yang melewati tiga kabupaten yaitu Kabupaten Grobogan, Kabupaten Kudus dan Kabupaten Demak. Pada Kabupaten Demak, Sungai Wulan mempunyai dua percabangan, yaitu Sungai Wulan Lama dan Sungai Wulan Baru. Sungai Wulan banyak digunakan oleh masyarakat setempat untuk berbagai aktivitas. Air sungai dimanfaatkan untuk berbagai keperluan seperti perikanan, kegiatan domestik dan transportasi yang diduga dapat mempengaruhi kondisi sungai. Di hilir Sungai Wulan juga terdapat daerah mangrove. Dampak dari kegiatan manusia tersebut kemungkinan akan berpengaruh terhadap kualitas perairan, hal tersebut diduga berdampak terhadap keberadaan organisme yang ada di perairan.

Salah satu organisme yang hidup di perairan sungai adalah fitoplankton. Fitoplankton adalah organisme mikroskopik yang hidup melayang, mengapung dalam air serta memiliki kemampuan bergerak yang terbatas. Fitoplankton berperan sebagai salah satu bioindikator yang mampu menggambarkan kondisi suatu perairan (Prabandani et al., 2007). Klorofil-a merupakan pigmen yang selalu ditemukan dalam fitoplankton dan merupakan pigmen yang terlibat langsung dalam proses fotosintesis.

Perubahan kondisi air di Sungai Wulan berdasarkan faktor biologi dapat dilihat dari fitoplankton berupa jumlah dan jenis yang ditemukan. Fitoplankton mampu melakukan fotosintesis karena mengandung klorofil-a sehingga distribusi klorofil-a menggambarkan fitoplankton dalam suatu perairan. Klorofil-a adalah pigmen yang umumnya ada pada fitoplankton dan fitoplankton merupakan faktor utama untuk menghasilkan produksi primer dalam rantai makanan di perairan. Selain faktor biologi, kondisi fisika dan kimia dalam perairan dapat memberi pengaruh terhadap kondisi perairan di Sungai Wulan. Informasi mengenai kandungan klorofil-a dan fitoplankton di Sungai Wulan masih sangat terbatas, untuk saat ini belum pernah dilakukan penelitian. Oleh karena itu perlu dilakukan penelitian di lokasi Sungai Wulan tersebut, yang berkaitan dengan pengaruh dari aktivitas manusia. Tujuan dari penelitian ini adalah untuk mengetahui kandungan klorofil-a, fitoplankton dan status perairan berdasarkan kandungan klorofil-a dan kelimpahan fitoplankton di perairan Sungai Wulan.

\section{MATERI DAN METODE PENELITIAN}

Penelitian ini menggunakan metode survei lapangan. Penentuan lokasi penelitian dilakukan secara purposif. Karakteristik dari setiap stasiun yang digunakan untuk penelitian tersaji pada Tabel 1. Lokasi sampling dapat dilihat pada Gambar 1. Variabel utama terdiri dari kandungan klorofil-a dan fitoplankton (jenis dan jumlah). Variabel penunjang yaitu variabel fisika dan kimia perairan yang dilakukan pada setiap titik pengambilan sampel. Pengukuran suhu air menggunakan termometer, kecerahan menggunakan secchi disk, kedalaman menggunakan tongkat, $\mathrm{pH}$ menggunakan $\mathrm{pH}$ paper, arus menggunakan bola arus dan oksigen terlarut menggunakan metode titrmetri. Pengukuran kandungan nitrat dan fosfat dilakukan di laboratorium.

Tabel 1. Karakteristik dari Setiap Stasiun Penelitian

\begin{tabular}{|c|c|}
\hline Stasiun & Karakteristik \\
\hline $\begin{array}{c}1 \\
\text { (Dekat dengan } \\
\text { Pemukiman) }\end{array}$ & $\begin{array}{l}\text { - Dekat dengan pemukiman warga yang buangan limbah domestik dari } \\
\text { kegiatan rumah tangga langsung menuju ke sungai } \\
\left(06^{0} 45^{\prime} 01,8^{\prime \prime}-110^{0} 35^{\prime} 17,8^{\prime \prime}\right) \\
\text { - } \quad \text { Lebar sungai } \pm 20 \text { meter }\end{array}$ \\
\hline $\begin{array}{c}2 \\
\text { (Wulan Baru) }\end{array}$ & $\begin{array}{ll} & \text { Terletak di Sungai Wulan Baru } \\
& \left(06^{0} 45^{\prime} 33,4^{\prime \prime}-110^{0} 33^{\prime} 20,2^{\prime \prime}\right) \\
- & \text { Lebar sungai } \pm 50-60 \text { meter } \\
\text { - } & \text { Jarak dari Stasun } 1 \text { ke Stasiun } 2 \pm 3,6 \mathrm{~km} \\
\text { - } & \text { Jalur transportasi kapal nelayan yang berukuran besar } \\
\text { - } & \text { Di sepanjang sungai banyak terdapat tambak ikan dan udang } \\
\text { - } & \text { Banyak terdapat mangrove yang tumbuh di pinggir sungai }\end{array}$ \\
\hline $\begin{array}{c}3 \\
\text { (Wulan Lama) }\end{array}$ & $\begin{array}{ll}\text { - } & \text { Terletak di Sungai Wulan Lama } \\
& \left(06^{0} 43,58,6 "-110^{0} 33^{\prime} 20,2^{\prime \prime}\right) \\
\text { - } & \text { Lebar sungai } \pm 30 \text { meter } \\
\text { - } & \text { Jarak dari Stasiun } 1 \text { ke Stasiun } 3 \pm 3,3 \mathrm{~km} \\
\text { - } & \text { Jalur transportasi kapal nelayan yang berukuran relatif lebih kecil } \\
\text { - } & \text { Di sepanjang sungai banyak terdapat tambak ikan dan udang } \\
\text { - } & \text { Banyak terdapat mangrove yang tumbuh di pinggir sungai }\end{array}$ \\
\hline
\end{tabular}




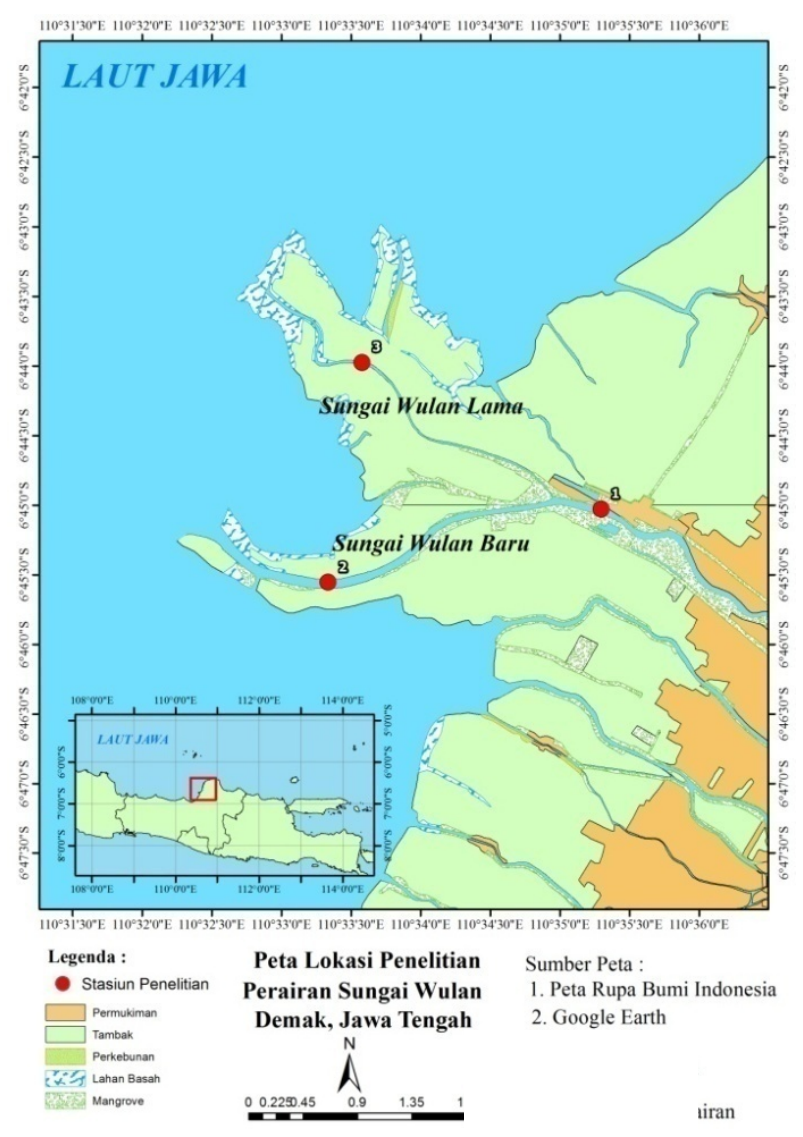

Gambar 1. Peta Stasiun Penelitian

Metode pengambilan sampel menggunakan metode Simple Random Sampling yang dilakukan pada 3 titik dari 3 stasiun yaitu sebanyak empat kali pengulangan dalam kurun waktu satu bulan. Pengambilan sampel dilakukan pada saat surut berdasarkan data tabel pasang surut. Sampel klorofil-a didapatkan 12 sampel dari ketiga stasiun dengan 4 kali pengulangan. Sampel fitoplankton setiap satu stasiun dilakukan tiga kali pengambilan sampel. Sehingga didapatkan 36 sampel untuk fitoplankton dari ketiga stasiun dengan 4 kali pengulangan.

\section{Klorofil-a}

Pengambilan sampel untuk uji klorofil-a dilakukan pada setiap stasiun sampling. Air sampel diambil sebanyak 1,5 liter dimasukkan ke dalam botol sampel berbahan plastik dan dimasukkan ke dalam cool box yang telah diisi es balok. Analisis klorofil-a menurut Radojevic dan Bashkin (1999) yaitu dengan menyaring air sebanyak 1,5 liter menggunakan kertas saring Whatman. Kertas saring yang telah digunakan untuk menyaring air sampel, kemudian dimasukkan ke dalam botol kaca tertutup yang berisi $15 \mathrm{ml}$ larutan aseton $90 \%$ untuk proses ekstraksi. Botol sampel disimpan pada suhu $4^{\circ} \mathrm{C}$ selama 12 - 14 jam. Setelah penyimpanan, larutan aseton yang ada di dalam botol kemudian diambil dan dimasukkan ke dalam tabung sentrifuge sebanyak $10 \mathrm{ml}$ kemudian diputar dalam sentrifuge dengan kecepatan $3500 \mathrm{rpm}$ selama 10 menit sehingga larutan menjadi jernih dan endapannya terkumpul di dasar. Kemudian sampel dituang ke kuvet (volume $5 \mathrm{ml}$ ) dan diabsorbansikan di UV-Vis spektrofotometer Optima Sp. $3000 \mathrm{Plus} \mathrm{pada}$ panjang gelombang 630, 647, 664, dan $750 \mathrm{~nm}$.

Perhitungan kandungan klorofil-a dilakukan dengan mengukur absorbansi pada panjang gelombang 630, 647, 664 dan $750 \mathrm{~nm}$ menggunakan spektrofotometer. Panjang gelombang $750 \mathrm{~nm}$ adalah faktor koreksi. Masing-masing angka absorbansi panjang gelombang 630, 647, dan $664 \mathrm{~nm}$ dikurangi dengan 1x faktor koreksi.

Kadar klorofil-a dihitung dengan rumus:

Keterangan:

$$
\text { Chl-a }=11,85 \mathrm{E}_{664}-1,54 \mathrm{E}_{647}-0,08 \mathrm{E}_{630}
$$

$\mathrm{E}=$ Simbol panjang gelombang yang digunakan pada spektrofotometer

Untuk menghitung kadar klorofil pada sampel air, maka angka absorbansi di atas dikalikan dengan faktor (k) Parsons et al. (1984):

$$
\text { Klorofil } \mathrm{mg} / \mathrm{m}^{3}=\frac{\operatorname{Cax} v}{V \times d}
$$




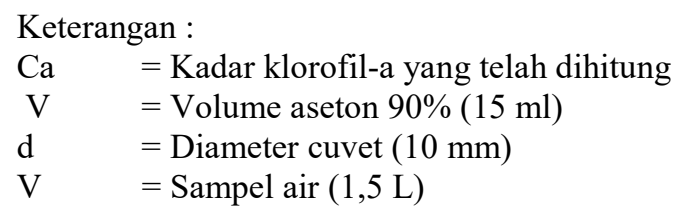

\section{Fitoplankton}

Pengambilan sampel plankton menggunakan plankton net berukuran $60 \mu \mathrm{m}$. Untuk pengambilan sampel plankton dilakukan dengan menggunakan metode filtrasi yaitu dengan cara mengambil air sampel sebanyak 100 liter. Sampel air disaring sebanyak 100 liter dengan menggunakan plankton net (Sachlan, 1982). Hasil penyaringan tersebut disimpan ke dalam botol sampel $50 \mathrm{ml}$ dan diberi $2-3$ tetes lugol iodine untuk mengawetkan sampel plankton.

Sampel yang telah diawetkan dikocok terlebih dahulu dengan cara botol sampel dikocok perlahan-lahan beberapa kali sampai teraduk dan tercampur. Setelah itu, diambil sebanyak $1 \mathrm{ml}$ dan diletakkan di Sedgwick-Rafter yang telah diletakkan object glass sebagai penutup. Kemudian diamati di bawah mikroskop binocular. Identifikasi dan perhitungan dilakukan dengan bantuan mikroskop binocular perbesaran 100x, dengan dilakukan pengulangan 3 kali pada 10 lapang pandang yang berbeda. Identifikasi fitoplankton dilakukan dengan menggunakan buku kunci identifikasi plankton Sachlan (1982), Yamaji (1996), Vuuren et al. (2006) dan Bellinger dan Sigee (2010).

Perhitungan kelimpahan fitoplankton per liter dilakukan dengan menggunakan rumus APHA (2005), yaitu:

$$
N=\frac{T}{L} \times \frac{P}{p} \times \frac{V}{v} \times \frac{1}{w}
$$

Keterangan :

$\mathrm{N}=$ Jumlah plankton per liter

$\mathrm{T}=$ luas total petak Sedgwick-Rafter $\left(1000 \mathrm{~mm}^{2}\right)$

$\mathrm{L}=$ luas lapang pandang mikroskop $\left(0,25 \mathrm{~mm}^{2}\right)$

$\mathrm{P}=$ jumlah plankton tercacah

$\mathrm{p}=$ jumlah lapang pandang yang diamati $(10)$

$\mathrm{V}=$ volume sampel plankton yang tersaring $(50 \mathrm{ml})$

$\mathrm{v}=$ volume sampel plankton dalam Sedgwick-rafter $(1 \mathrm{ml})$

$\mathrm{W}=$ volume sampel air yang tersaring $(1,5 \mathrm{~L})$

\section{Analisis Data}

Analisis Kruskal-Wallis digunakan untuk mengetahui perbedaan kandungan klorofil-a antar stasiun. Analisis Cluster digunakan untuk mengetahui kemiripan berdasarkan komunitas fitoplankton dan kemiripan berdasarkan variabel lingkungan antar stasiun. Analisis dilakukan dengan bantuan perangkat lunak PAST3.

\section{HASIL DAN PEMBAHASAN}

\section{Klorofil-a}

Hasil pengukuran klorofil-a selama pengamatan dapat dilihat pada Tabel 2.

Tabel 2. Hasil Pengukuran Kandungan Klorofil-a (mg/l) per Ulangan pada Masing-masing Stasiun

\begin{tabular}{cccc}
\hline \multirow{2}{*}{ Ulangan } & \multicolumn{3}{c}{ Stasiun } \\
\cline { 2 - 4 } & $\mathbf{1}$ & $\mathbf{2}$ & $\mathbf{3}$ \\
\hline 1 & 0,6547 & 0,5114 & 1,3996 \\
2 & 0,4109 & 0,4235 & 2,7581 \\
3 & 0,0510 & 0,1104 & 0,1014 \\
4 & 0,8665 & 1,0391 & 1,1584 \\
\hline Rata-rata \pm SD & $0,4955 \pm 0,3497$ & $0,5211 \pm 0,3859$ & $1,3527 \pm 1,0926$ \\
\hline
\end{tabular}

Berdasarkan Tabel 2 kandungan klorofil-a pada tabel menunjukkan bahwa rata-rata tertinggi kandungan klorofila terdapat pada Stasiun 3 yaitu 1,3527 mg/l. Kandungan klorofil terdapat pada Stasiun 1 dengan rata-rata yaitu 0,4955 $\mathrm{mg} / \mathrm{l}$. Pada Stasiun 2 mempunyai rata-rata sebesar $0,5211 \mathrm{mg} / \mathrm{l}$. Berdasarkan rata-rata klorofil-a yang diperoleh, perairan Sungai Wulan tergolong kedalam perairan yang bersifat oligotrofik. Penggolongan tersebut berdasarkan status trofik perairan menurut Parslow et al. (2008) yakni kandungan klorofil pada kisaran $0-2 \mathrm{mg} / 1$ tergolong oligotrofik, $2-5$ $\mathrm{mg} / \mathrm{l}$ tergolong meso-oligotrofik, $5-20 \mathrm{mg} / 1$ tergolong mesotrofik, $20-50 \mathrm{mg} / 1$ tergolong eurotrofik dan $>50 \mathrm{mg} / 1$ tergolong hiper-eurotrofik.

Untuk mengetahui apakah ada perbedaan kandungan klorofil-a antar stasiun, data selanjutnya diuji dengan menggunakan analisis Kruskal Wallis. Hasil analisis tersaji pada Tabel 3.

Tabel 3. Hasil Signifikasi Uji Kruskal Wallis Antar Stasiun 


\begin{tabular}{lc}
\hline Analisis Uji & Asumsi Signifikansi \\
\hline Klorofil-a & 0,298 \\
\hline
\end{tabular}

Berdasarkan Tabel 4 asumsi signifikansi (P) kandungan klorofil-a yang diperoleh sebesar 0,298. Artinya adalah kandungan klorofil-a tidak ada perbedaan yang nyata antar stasiun apabila digunakan $\alpha(0,05)$.

\section{Fitoplankton}

Pengamatan di lokasi penelitian di Sungai Wulan ditemukan 5 kelas yaitu kelas Bacillariophyceae (13 genera), kelas Cyanophyceae (5 genera), kelas Dynophyceae (3 genera), kelas Chlorophyceae (12 genera) dan kelas Euglenophyceae ( 2 genera). Kelimpahan fitoplankton pada masing-masing stasiun tersaji pada Tabel 4.

Tabel 4. Kelimpahan Rata-Rata Fitoplankton (ind/l) per Genus pada Masing-masing Stasiun

\begin{tabular}{|c|c|c|c|c|}
\hline \multirow{2}{*}{ No. } & \multirow{2}{*}{ Kelas \& Genera } & \multicolumn{3}{|c|}{ Stasiun } \\
\hline & & 1 & 2 & 3 \\
\hline & Bacillariophyceae & & & \\
\hline 1. & Nitzschia & 1.256 & 1.533 & 2.683 \\
\hline 2. & Navicula & 1.150 & 1.428 & 694 \\
\hline 3. & Hyalodiscus & 294 & 433 & 494 \\
\hline 4. & Triceratium & - & 11 & - \\
\hline 5. & Melosira & - & 17 & - \\
\hline 6. & Coscinodiscus & 28 & 122 & 172 \\
\hline 7. & Skeletonema & 611 & 683 & 756 \\
\hline 8. & Pleurosigma & 17 & 56 & 67 \\
\hline 9. & Thallasiosira & 117 & - & 67 \\
\hline 10. & Aulacosira & 17 & 206 & 267 \\
\hline 11. & Asterionella & - & 17 & 44 \\
\hline 12. & Licmophora & 50 & 100 & 189 \\
\hline \multirow{2}{*}{13.} & Surirella & - & - & 17 \\
\hline & Cyanophyceae & & & \\
\hline 14. & Oscillatoria & 367 & 1.189 & 272 \\
\hline 15. & Trichodesmium & 2.017 & 1.567 & 1.356 \\
\hline 16. & Cylindrospermopsis & 289 & 100 & 117 \\
\hline 17. & Anabaena & 356 & 539 & 661 \\
\hline \multirow{2}{*}{18.} & Spirulina & 178 & 172 & 89 \\
\hline & Dynophyceae & & & \\
\hline 19. & Peridinium & - & 22 & - \\
\hline 20. & Protoperidinium & 94 & - & - \\
\hline \multirow[t]{2}{*}{21.} & Ceratium & 39 & - & - \\
\hline & Chlorophyceae & & & \\
\hline 22. & Pediastrum & 717 & 1.400 & 1622 \\
\hline 23. & Closterium & 356 & 244 & 256 \\
\hline 24. & Haematococcus & 117 & 133 & 144 \\
\hline 25. & Coelastrum & 44 & 128 & 56 \\
\hline 26. & Crucigenia & 200 & 328 & 244 \\
\hline 27. & Actinastrum & 333 & 372 & 794 \\
\hline 28. & Scenedesmus & 278 & 489 & 406 \\
\hline 29. & Spirogyra & 83 & 33 & 100 \\
\hline 30. & Microcystis & 128 & 150 & 250 \\
\hline 31. & Sphaerocystis & 11 & 117 & 144 \\
\hline 32. & Selenastrum & 28 & - & - \\
\hline \multirow[t]{2}{*}{33.} & Stigeoclonium & - & 11 & - \\
\hline & Euglenophyceae & & & \\
\hline 34 & Phacus & 233 & 228 & 228 \\
\hline \multirow[t]{3}{*}{35} & Euglena & 50 & 11 & 233 \\
\hline & Jumlah Kelimpahan & 9.458 & 11.839 & 12.422 \\
\hline & Jumlah Genus & 29 & 30 & 28 \\
\hline
\end{tabular}

Berdasarkan hasil pada Tabel 5, kelimpahan fitoplankton yang paling tinggi terdapat pada Stasiun 3. Dari keseluruhan fitoplankton yang didapat, kelas yang mendominasi adalah Bacillariophyceae berdasarkan jumlah genus 
yang ditemukan per kelas. Pada Stasiun 1 yang mendominasi adalah dari genus Nitzschia, Navicula, Skeletonema, Thallasiosira, Trichodesmium dan Pediastrum. Pada Stasiun 2 yang mendominasi adalah dari genus Nitzschia, Navicula, Skeletonema, Trichodesmium, Anabaena dan Pediastrum. Dan pada Stasiun 3 yang dominan adalah genus Nitzschia, Navicula, Skeletonema, Trichodesmium, Pediastrum dan Actinastrum. Berdasarkan kelimpahan fitoplankton yang diperoleh, perairan Sungai Wulan tergolong ke dalam perairan yang bersifat mesotrofik. Penggolongan tersebut berdasarkan status trofik perairan menurut Basmi (1994) bahwa suatu perairan diklasifikasikan oligotrofik (kesuburan perairan rendah) bila mempunyai kelimpahan individu planktonnya $<2.000 \mathrm{ind} / 1$, mesotrofik (kesuburan perairan sedang) bila mempunyai kelimpahan planktonnya $2.000-15.000 \mathrm{ind} / 1$ dan eutrofik (kesuburan perairan tingg) bila kelimpahan plankton $>15.000 \mathrm{ind} / 1$.

Pengelompokkan stasiun berdasarkan komunitas fitoplankton adalah sebagai berikut dalam Gambar 2.

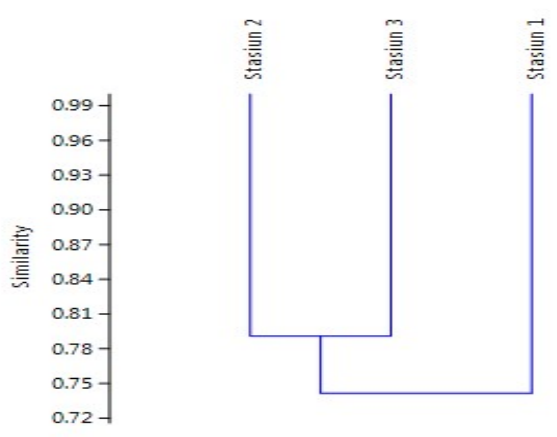

Gambar 2. Hasil Analisis Cluster Antar Stasiun Berdasarkan Komunitas Fitoplankton

Hasil dari analisis cluster antar stasiun berdasarkan komunitas fitoplankton menunjukkan bahwa Stasiun 2 dan Stasiun 3 memiliki kemiripan yaitu $\pm 79 \%$. Sedangkan kemiripan untuk Stasiun 1 terhadap Stasiun 2 dan Stasiun 3 yaitu $\pm 74 \%$. Diantara ketiga stasiun, Stasiun 2 dan Stasiun 3 mempunyai kemiripan yang tinggi. Hal ini dikarenakan ada beberapa genus fitoplankton yang ditemukan mempunyai jumlah dan jenis yang sama dan juga genus yang tidak ditemukan di kedua stasiun. Fitoplankton yang ditemukan di Stasiun 2 dan Stasiun 3 antara lain dari genus Nitzschia, Hyalodiscus, Coscinodiscus, Skeletonema, Pleurosigma, Aulacosira, Asterionella, Licmophora, Anabaena, Pediastrum, Haematococcus, Coelastrum, Crucigenia, Actinastrum, Scenedesmus, Microcystis dan Sphaerocystis. Sedangkan fitoplankton yang tidak ditemukan di Stasiun 2 dan Stasiun 3 antara lain dari genus Protoperidinium, Ceratium dan Selenastrum.

\section{Variabel lingkungan} Tabel 6.

Hasil pengukuran variabel lingkungan perairan yang didapatkan selama penelitian di Sungai Wulan tersaji pada

Tabel 6. Hasil Pengukuran Variabel Lingkungan di Masing - masing Stasiun

\begin{tabular}{lccc}
\hline \multirow{2}{*}{ Variabel } & \multicolumn{3}{c}{ Stasiun } \\
\cline { 2 - 4 } & $\mathbf{1}$ & $\mathbf{2}$ & $\mathbf{3}$ \\
\hline Kecerahan $(\mathrm{cm})$ & $10-38$ & $15-52$ & $18-45$ \\
Kedalaman $(\mathrm{m})$ & 3 & 2,5 & 1 \\
Suhu Air $\left({ }^{0} \mathrm{C}\right)$ & $31-33$ & $31-33$ & $33-34$ \\
Arus $(\mathrm{m} / \mathrm{s})$ & $0,17-0,33$ & $0,11-0,25$ & $0,10-0,17$ \\
DO $(\mathrm{mg} / \mathrm{l})$ & $3,1-5,2$ & $3,57-6,9$ & $3,16-5,9$ \\
$\mathrm{pH}$ & 6 & 6 & 6 \\
\hline
\end{tabular}

Berdasarkan Tabel 6 menunjukkan bahwa diantara ketiga stasiun yang mempunyai kecerahan yang paling bagus adalah di Stasiun 1 berkisar $15-52 \mathrm{~cm}$. Suhu air di ketiga stasiun relatif sama yaitu $31-34{ }^{\circ} \mathrm{C}$. Arus air yang mempunyai aliran yang cepat adalah di Stasiun 2 yaitu sebesar $0,17-0,33 \mathrm{~m} / \mathrm{s}$. Untuk kandungan oksigen terlarut, Stasiun 1 mempunyai kandungan yang tinggi yaitu 3,57 - 6,8 mg/l. Ketiga stasiun mempunyai $\mathrm{pH}$ yang sama yaitu 6 . Kandungan nitrat yang paling tinggi berada di Stasiun 1 berkisar antara 1,323 - 2,757 mg/l. Sedangkan untuk kandungan fosfat yang paling tinggi terdapat di Stasiun 1 yaitu sebesar 0,077 - 0,141 mg/l. Pengukuran salinitas juga dilakukan, tetapi hasil dari ketiga stasiun $0 \%$. Hasil analisis kandungan nitrat berkisar antara 1,315 - 2,757 mg/l dan fosfat berkisar antara $0,077-0,141 \mathrm{mg} / \mathrm{l}$. Kandungan nitrat dan fosfat di lokasi penelitian dapat dilihat pada Gambar 3 . 


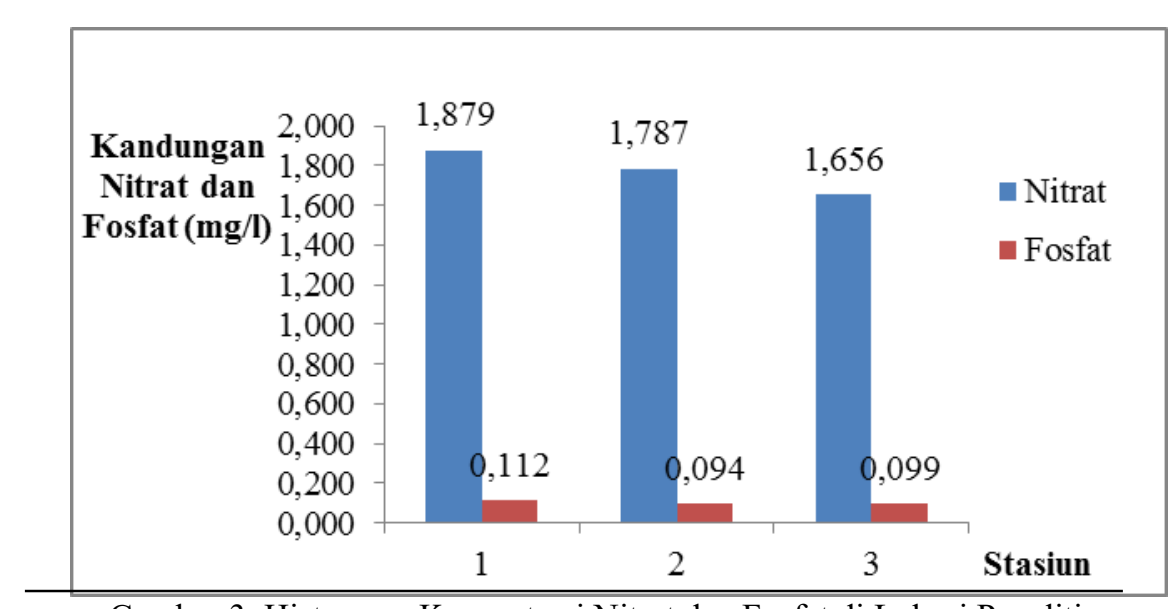

Gambar 3. Histogram Konsentrasi Nitrat dan Fosfat di Lokasi Penelitian

Berdasarkan Gambar 3 rerata kandungan nitrat yang paling tinggi terdapat pada Stasiun 1 yaitu $1,879 \mathrm{mg} / \mathrm{l}$. Kandungan fosfat pada Stasiun 1 juga paling tinggi yaitu $0,112 \mathrm{mg} / 1$. Dari hasil beberapa variabel penunjang perairan, kualitas air yang paling bagus terdapat pada Stasiun 1 dan 2.

Pengelompokan stasiun berdasarkan variabel lingkungan adalah sebagai berikut dalam Gambar 4.

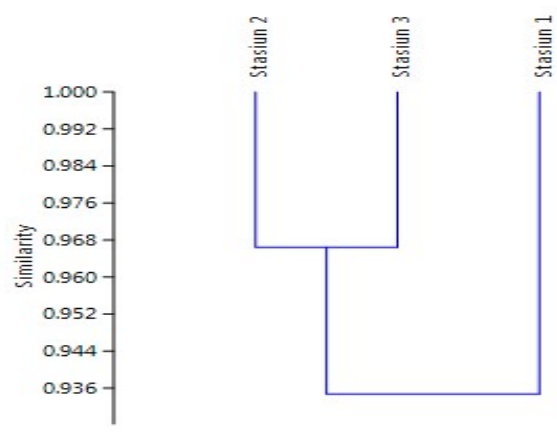

Gambar 4. Hasil Analisis Cluster Antar Stasiun Berdasarkan Variabel Lingkungan

Kemiripan berdasarkan variabel lingkungan antara Stasiun 1, 2 dan 3 tersaji pada Gambar 4. Variabel lingkungan yang dianalisis antara lain kedalaman, kecerahan, suhu air, arus air, oksigen terlarut, $\mathrm{pH}$, kandungan nitrat dan fosfat. Hasil dari analisis menunjukkan bahwa stasiun 2 dan stasiun 3 memiliki kemiripan yaitu $\pm 96,7 \%$. Kemiripan untuk Stasiun 1 terhadap Stasiun 2 dan Stasiun 3 yaitu \pm 93,6 \%.

Hasil dari pengukuran variabel lingkungan di Sungai Wulan menunjukkan hasil yang berbeda antar stasiun dengan kegiatan manusia yang berbeda. Kegiatan manusia tersebut akan berpengaruh terhadap fitoplankton tetapi tidak secara langsung. Kegiatan manusia akan mempengaruhi perubahan kualitas perairan di sungai, dan kemudian perubahan tersebut akan berpengaruh terhadap fitoplankton.

\section{Pembahasan}

Hasil identifikasi dan perhitungan kelimpahan fitoplankton yang diperoleh dari ketiga stasiun diketahui bahwa komposisi komunitas fitoplankton di Sungai Wulan ditemukan 5 kelas yaitu kelas Bacillariophyceae (13 genera), kelas Cyanophyceae (5 genera), kelas Dynophyceae (3 genera), kelas Chlorophyceae (12 genera) dan kelas Euglenophyceae (2 genera). Dua kelas yang mendominasi adalah dari kelas Bacillariophyceae dan kelas Chlorophyceae.

Beberapa penelitian terdahulu mengenai fitoplankton di beberapa sungai di wilayah Indonesia memperlihatkan kecenderungan dominansi yang sama, seperti di Sungai Rokan, Provinsi Riau ditemukan genus fitoplankton yang terdiri dari 19 genera dari kelas Bacillariophyceae, 15 genera dari Chlorophyceae dan 8 genera dari kelas Cyanophyceae (Dwirastina dan Makri, 2014). Penelitian lain oleh Adani et al. (2013) menemukan bahwa dari 21 genera fitoplankton yang diidentifikasi di Sungai Wedung Kabupaten Demak Provinsi Jawa Tengah 11 genera adalah kelas Bacillariophyceae, 4 genera dari kelas Cyanophyceae, 5 genera dari kelas Chlorophyceae dan 1 genera dari kelas Pypropyta.

Kelas Bacillariophyceae dan Chlorophyceae merupakan kelompok besar penyusun komunitas fitoplankton yang ada di perairan Sungai Wulan dan beberapa sungai pada umumnya. Menurut Adjie et al. (2003), Bacillariophyceae adalah salah satu kelompok algae yang secara kualitatif dan kuantitatif banyak terdapat di berbagai perairan tipe sungai, 
baik sebagai plankton maupun sebagai perifiton, sedangkan Chlorophyceae yang termasuk ke dalam filum Chlorophyra paling banyak dijumpai di perairan tawar.

Peridinium, Protoperdinium, dan Ceratium merupakan jenis fitoplankton dari kelas Dinophyceae dan Dinoflagelatta. Jumlah dari kelas Dinophyceae sedikit diantara kelas lainnya setelah kelas Euglenophyceae yang paling sedikit. Jumlah Dinophyceae sedikit diduga karena kondisi Sungai Wulan masih dalam batas normal namun apabila limbah yang masuk berlebihan dapat berpengaruh terhadap jumlah dari kelas Dinophyceae. Kelas Euglenophyceae merupakan kelas dari fitoplankton yang paling sedikit ditemukan di Sungai Wulan. Genus yang ditemukan dari kelas Euglenophyceae antara lain Phacus dan Euglena.

Berdasarkan kelimpahan fitoplankton yang diperoleh, perairan Sungai Wulan tergolong ke dalam perairan yang bersifat mesotrofik. Stasiun 3 yang memiliki kelimpahan fitoplankton yang tinggi juga diduga karena lokasi penelitian dekat dengan tambak dimana buangan air limbah pakan ikan dan sisa metabolisme dapat menambah unsur hara. Selain itu juga di sekitar lokasi terdapat mangrove dan tumbuh subur. Menurut Wiadnyana (2002), mangrove berfungsi sebagai pemasok unsur hara di perairan, nutrien serasah mangrove dapat dimanfaatkan oleh fitoplankton untuk pertumbuhan dan perkembangannya. Kelimpahan tertinggi kedua adalah Stasiun 2. Karakteristik untuk stasiun 2 hampir sama dengan Stasiun 3, yaitu terdapat mangrove dan tambak di sekitar aliran sungai.

Kelimpahan fitoplankton terendah adalah berada di stasiun 1. Stasiun 1 merupakan lokasi penelitian yang dekat dengan pemukiman penduduk. Sungai dimanfaatkan oleh penduduk untuk MCK dan pembuangan limbah rumah tangga. Menurut Jannah dan Zainal (2012), rendahnya kelimpahan fitoplankton pada stasiun yang berada di sekitar pemukiman penduduk dikarenakan aktifitas-aktifitas yang terjadi akan sangat berpengaruh terhadap rendahnya kelimpahan fitoplankton karena dengan adanya buangan limbah dan sampah organik dan anorganik dari pemukiman penduduk menyebabkan perairan di sekitar stasiun tersebut menjadi keruh, sehingga dapat menghalangi penetrasi sinar matahari ke peraian.

Berdasarkan kandungan klorofil-a yang diperoleh, perairan Sungai Wulan tergolong ke dalam perairan yang bersifat oligotrofik. Penelitian terdahulu mengenai klorofil-a di sungai di wilayah Indonesia memperlihatkan nilai yang berbeda antar lokasi. Seperti penelitian oleh Adani et al. (2013) di Sungai Wedung, Demak, diperoleh nilai klorofil-a yang berbeda yaitu $1,149 \mathrm{mg} /, 1,022 \mathrm{mg} / \mathrm{l}$ dan $0,949 \mathrm{mg} / \mathrm{l}$. Hasil dari penelitian oleh Calijuri et al.(2008) di Sungai Jacupiranguinha dan Sungai Pariquera-Açu yang termasuk sungai tropis di Negara Brazil, menunjukkan nilai kandungan klorofil-a yang bervariasi antar lokasi penelitian. Sungai Jacupiranguinha mempunyai kandungan klorofil-a yaitu $1,2 \mathrm{mg} / 1,1,4 \mathrm{mg} / 1,3,0 \mathrm{mg} / \mathrm{l}$ dan $3,7 \mathrm{mg} / \mathrm{l}$. Sedangkan pada Sungai Pariquera-Açu mempunyai kandungan klorofila yaitu $0,6 \mathrm{mg} / 1,0,3 \mathrm{mg} / 1,1,5 \mathrm{mg} / \mathrm{l}$ dan $4,6 \mathrm{mg} / 1$.

Kandungan klorofil-a di Sungai Wulan paling tinggi terdapat pada stasiun 3 terletak pada Sungai Wulan Lama. Hasil pengamatan kelimpahan fitoplankton didapatkan untuk stasiun 1 yaitu $9.458 \mathrm{ind} / 1$, stasiun 2 yaitu $11.839 \mathrm{ind} / 1$ dan stasiun 3 yaitu 12.422 ind/l. Dari hasil tersebut menunjukkan bahwa stasiun 1 sampai stasiun 3 jumlah dari kelimpahan fitoplankton semakin bertambah, maka kandungan klorofil-a juga semakin meningkat. Hal ini didukung oleh Sulastri et al. (2002) bahwa meningkatnya kandungan klorofil-a disebabkan oleh meningkatnya kelimpahan fitoplankton.

Kecepatan Arus di perairan Sungai Wulan pada saat pengukuran di dapatkan kecepatan arus pada stasiun 1 antara $0,17 \mathrm{~m} / \mathrm{s}$, stasiun 2 antara $0,11-0,25 \mathrm{~m} / \mathrm{s}$, dan stasiun 3 antara $0,10-0,17 \mathrm{~m} / \mathrm{s}$. Adanya arus pada ekosistem akuatik membawa plankton khususnya fitoplankton yang menumpuk pada tempat tertentu. Jika tempat baru itu kaya akan nutrisi yang menunjang pertumbuhan fitoplankton dengan faktor abiotik yang mendukung bagi pertumbuhan kehidupan plankton (Basmi, 1995). Pengaruh arus bagi organisme air yang paling penting adalah ancaman bagi organisme tersebut dihanyutkan oleh arus yang deras.

Oksigen terlarut di Sungai Wulan pada stasiun antara 3,1-5,2 mg/l, pada stasiun 2 antara 3,57-6,9 mg/l, dan stasiun 3 antara 3,16 - 5,9 mg/l. Kisaran ini masih sesuai dengan pertumbuhan fitoplankton. Dilihat dari kandungan oksigen terlarut lebih besar dari $3 \mathrm{mg} / \mathrm{l}$ maka kehidupan kebanyakan organisme lainnya masih dapat hidup dengan layak (Wardoyo, 1982). Suhu perairan di 3 stasiun penelitian memiliki perbedaan yang signifikan. Hal ini disebabkan karena pengukuran suhu perairan dilakukan dalam waktu yang berbeda yaitu pada pukul $11.00-14.00$ WIB. Suhu berpengaruh terhadap distribusi fitoplankton. Menurut Effendi (2003), kisaran suhu optimum bagi pertumbuhan fitoplankton di perairan adalah $20-30{ }^{\circ} \mathrm{C}$. Pengukuran $\mathrm{pH}$ pada lokasi penelitian adalah 6 . Nilai $\mathrm{pH}$ yang terdapat pada masing-masing stasiun tidak memperlihatkan perbedaan yang signifikan dan berada dalam kondidi normal. Menurut PP No. 82 tahun 2001, dalam kriteria baku mutu air kelas III (untuk perikanan) adalah 6 - 9. Dengan demikian, nilai pH yang terdapat pada setiap stasiun penelitian dapat disimpulkatn bahwa perairan tersebut tergolong kepada perairan yang produktif untuk kehidupan organisme fitoplankton dan berada di bawah ambang batas yang ditetapkan.

Kandungan nitrat dan fosfat tertinggi terdapat pada stasiun 1, sedangkan konsentrasi nitrat terendah terdapat pada stasiun 2. Kandungan nitrat tinggi di stasiun 1 dengan lokasi berada tepat pada pemukiman penduduk sehingga memberikan sumbangan yang cukup besar dari daratan yang masuk ke perairan. Nitrat dan fosfat yang tinggi bisa dilihat pada histogram (Gambar 3). Secara teoritis kondisi di lapangan sesuai dengan teori bahwa di dekat pemukiman kandungan nitrat dan fosfat akan tinggi. Menurut Alaerts dan Santika (1987), kadar nitrat yang tinggi di perairan disebabkan oleh masuknya limbah domestik, pertanian peternakan dan industri. Menurut Effendi (2003) sumber antropogenik fosfor seperti limbah industri dan domestik, fosfor yang berasal dari deterjen, limpasan dari pertanian yang mengandung pupuk juga memberikan kontribusi besar bagi keberadaan fosfat.

Hasil analisa cluster antar stasiun berdasarkan variabel lingkungan dan berdasarkan komunitas fitoplankton menunjukkan hasil yang sama (Gambar 2 dan Gambar 4). Stasiun 2 dan Stasiun 3 lebih mempunyai kemiripan, 
dibandingkan dengan Stasiun 1. Kemiripan pada Stasiun 2 dan Stasiun 3 disebabkan karena letak dari stasiun sama yaitu pada cabang dari sungai yang menuju ke daerah muara. Sehingga kondisi fisika dan kimia kedua kelompok stasiun tersebut mendekati sama dan diduga akan berpengaruh terhadap kelimpahan di Stasiun 2 dan Stasiun 3.

\section{KESIMPULAN}

Kesimpulan yang diperoleh dari penelitian ini adalah sebagai berikut:

Kandungan klorofil-a pada lokasi yang berbeda di Sungai Wulan, rata-rata untuk stasiun 1 adalah $0,4955 \mathrm{mg} / \mathrm{l}$, stasiun 2 adalah $0,5211 \mathrm{mg} / \mathrm{l}$ dan stasiun 3 adalah $1,3527 \mathrm{mg} / \mathrm{l}$. Tidak ada perbedaan yang nyata kandungan klorofil-a antar stasiun pada taraf kepercayaan 95\% $(0,05)$. Fitoplankton pada lokasi yang berbeda di Sungai Wulan memiliki kelimpahan rata-rata pada Stasiun 1 sebanyak 9.458 ind/l, pada Stasiun 2 sebanyak 11.839 ind/1 dan Stasiun 3 sebanyak 12.422 ind/l. Fitoplankton yang diperoleh dari ketiga stasiun terdiri dari 5 kelas dan 35 genera yaitu kelas Bacillariophyceae (13 genera), kelas Cyanophyceae (5 genera), kelas Dynophyceae (3 genera), kelas Chlorophyceae (12 genera) dan kelas Euglenophyceae ( 2 genera). Komunitas fitoplankton di Stasiun 2 dan Stasiun 3 lebih mirip dibandingkan dengan Stasiun 1. Variabel lingkungan antara Stasiun 2 dan Stasiun 3 juga lebih mirip dibandingkan dengan Stasiun 1. Status perairan Sungai Wulan berdasarkan kandungan klorofil-a tergolong oligotrofik dan berdasarkan kelimpahan fitoplankton tergolong mesotrofik.

\section{UCAPAN TERIMA KASIH}

Penulis mengucapkan terima kasih kepada Allah SWT yang telah memberikan rahmat dan karunia-Nya sehingga penulis dapat menyelesaikan penelitian ini. Terima kasih kepada Prof. Norma Afiati M.Sc, Ph.D, Dr. Ir. Bambang Sulardiono, M.Si dan Dr. Ir. Max Rudolf Muskananfola, M.Sc, untuk saran dan masukannya di dalam penyusunan penulisan ini. Serta kepada seluruh pihak yang membantu selama penelitian ini.

\section{DAFTAR PUSTAKA}

Adani, N. G., M. R. Muskanonfola dan I. B. Hendrarto. 2013. Kesuburan Perairan Ditinjuau dari Kandungan Klorofil-a Fitoplankton: Studi Kasus di Sungai Wedung, Demak. Diponegoro Journal of Maquares, 2(4): 38-45.

Adithya, R., T. S. Raza'i dan A. Zulfikar. 2015. Keanekaragaman dan Kelimpahan Fitoplankton di Sungai Ekang Anculai Kecamatan Teluk Sebong Kabupaten Bintan, 1(1): 1-9.

Adjie, S., Samuel dan Subagja. 2003. Kelimpahan dan Keragaman Plankton di Danau Arang-Arang, Jambi. Jurnal Penelitian Perikanan Indonesia, 9(7): 1-7.

Alaerts, G. dan S.S. Santika 1987. Metoda Penelitian Air. Penerbit Usaha Nasional, Surabaya.

[APHA] American Public Health Association. 2005. Standard Methods for The Examination of Water and Waste Water Including Bottom Sediment and Sludges. Publ. Health Association Inc, New York.

Basmi, J. 1994. Planktonologi: Teknik Menghitung Plankton. Jurusan Manajemen Sumberdaya Perairan, Fakultas Perikanan dan Ilmu Kelautan, Institut Pertanian Bogor, Bogor.

. 1995. Planktonologi: Organisme Penyusun Plankton, Klasifikasi dan Terminologi, Hubungan antara Fitoplankton dan Zooplankton, Siklus Produksi Umumnya di Perairan. Fakultas Perikanan dan Ilmu Kelautan. Institut Pertanian Bogor, Bogor.

Bellinger, E. G. dan D. C. Sigee. 2010. Freshwater Algae: Identification and Use as Bioindicators. John Wiley \& Sons Ltd, London.

Boyd, C. E. 1990. Water Quality in Ponds for Agriculture, Alabama. Agricultural Experiment Station, Auburn University, Alabama.

Calijuri, M.C., Cunha, D.G.F., Queiroz, .., Moccellin, J., dan Miwa, A.C.P. 2008. Nutrients and Chlorophyll-a Concentrations in Tropical Rivers of Ribeira de Iguape Basin, SP, Brazil. Acta Limnol. 20(2): 131 - 138.

Dwirastina, M., dan Makri. 2014. Distribusi Spasial terhadap kelimpahan, Biomassa fitoplankton dan Keterkaitannya dengan Kesuburan Perairan di Sungai Rokan, Provinsi Riau. Limnotek, 21(2): 115-124.

Jannah, R. dan A. M. Zainal. 2012. Komunitas fitoplankton di Daerah Estuaria Krueng Aceh, Kota Banda Aceh. Jurnal Depik, 1(3): 189-195.

Parslow, J., J. Hunter and A. Davidson. 2008. Estuarine Eutrophication Models. Final Report Project E6 National River Health Program. Water Services Association of Australian Melbourne Australia. CSIRO Marine Research. Hobarth, Tasmania.

Parsons, T. R., M. Takeshi and B. Hagrave. 1984. Biological Oceanographic Processes. Third Edition. Oxford.

Peraturan Pemerintah No. 82 tahun 2001 tentang Pengelolaan Kualitas Air dan Pengendalian Pencemaran Air. 
Prabandani, D. Diah, B.S. Setiani dan A. Sabar. 2007. Komposisi Plankton di Perairan Waduk Saguling, Jawa Barat. Lingkungan Tropis Edisi khusus Agustus 2007. IATPI, Bandung.

Radojevic, M. D. dan V. N. Bashkin. 1999. Pratical Environmental Analysis. Royal Society of Chemistry, Cambridge.

Sachlan, M. 1982. Planktonologi. Fakultas Peternakan Universitas Pergamon Press. Great Britain.Diponegoro, Semarang.

Sari, M., S. Adyatma dan E. Normelani. 2016. Pemanfaatan Air Sungai Alalak Utara oleh Masyarakat di Bantaran Sungai Alalak Utara di Kelurahan Alalak Utara Kecamatan Banjarmasin Utara Kota Banjarmasin. Jurnal Pendidikan Geografi. 3(2): 33-41.

Sulastri, A. dan Lukisubehi. 2002. Perubahan Komposisi Fitoplankton dan Tingkat Eutrofikasi Danau Maninjau Sumatra Barat. Lembaga Ilmu Pengetahuan Indonesia, LIPI Press, Jakarta.

Vuuren, S. J. V., J. Taylor, C. V. Ginkel dan A. Gerber. 2006. Easy Identification of the Most Common Freshwater Algae. A Guide for the Identification of Microscopic Algae in South African Freshwaters. ISBN 0-621-35471-6.

Wardoyo, S.T.H. 1982. Water Analysis Manual Tropical Aquatiz Biology Program Biotrop-Seameo, Bogor.

Effendi, H. 2003. Telaah Kualitas Air. Kanisius, Yogyakarta.

Wiadnyana. N. N. 2002. Kesuburan dan Komunitas Plankton di Perairan Pesisir Digul, Irian Jaya. Jurnal Ilmu-ilmu Perairan dan Perikanan Indonesia, 31:57-68.

Wibowo, H. P. E., T. Purnomo dan R. Ambarwati. 2014. Kualitas Perairan Sungai Bengawan Solo di Wilayah Kabupaten Bojonegoro Berdasarkan Indeks Keanekaragaman Plankton. Jurnal Lentera Bio. 3(3): 209-215.

Wijayanti. 2011. Keanekaragaman Jenis Plankton pada Tempat yang Berbeda Kondisi Lingkungannya di Rawa Pening Kabupaten Semarang. [Skripsi]. IKIP PGRI Semarang, Semarang.

Yamaji, I. 1996. Illustration of the Marine Plankton of Japan. Hoikusho, Japan. 